\title{
Influence of microwaves on olive oil stability
}

\author{
By R. S. Farag*, G. El-Baroty ${ }^{\star}$, N. Abd-El-Aziz ${ }^{\star \star}$ and A. M. Basuny ${ }^{\star \star}$ \\ * Department of Biochemistry, Faculty of Agriculture, Cairo University, Giza, Egypt. \\ ** Department of Food Technology Agriculture Research Center, Ministry of Agriculture, Giza, Egypt.
}

\section{RESUMEN}

Influencia del tratamiento con microondas sobre la estabilidad del aceite de oliva.

Aceitunas de las variedades Picual y Shemlalli fueron expuestas a una fuente de microondas generadas en un horno a potencia baja y moderada durante $3,6,9$ y 12 minutos. Se determinaron las constantes físico-químicas y la composición en ácidos grasos de muestras de aceite de oliva extraído de aceitunas irradiadas y no irradiadas con microondas. Los datos demostraron que la irradiación con microondas no altera los valores de los parámetros antes mencionados si se compara con el aceite extraído de aceitunas no irradiadas.

Los tests de garantía de calidad (índice de acidez, índice de peróxido y TBA) mostraron que la irradiación con microonda aumentó la estabilidad del aceite de oliva de las variedades Picual y Shemlalli durante su almacenamiento. En suma, la irradiación con microondas generadas en horno a potencia moderada durante 12 minutos produce un poder antioxidante sobre el aceite de oliva equivalente al que se obtuvo con el BHT a 200 ppm.

PALABRAS-CLAVE: Aceite de oliva - Efecto antioxidante Estabilidad - Microondas.

\section{SUMMARY}

\section{Influence of microwaves on olive oil stability}

The fruits of Picual and Shemlalli olive cultivars were exposed to microwaves generated from an oven at low and moderate power settings for 3, 6, 9 and $12 \mathrm{~min}$. The physicochemical constants and fatty acid composition of the olive oil samples extracted from nonmicrowaved and microwaved fruits were determined. The data demonstrated that microwaves did not alter the values of the above mentioned parameters compared with the oil extracted from nonmicrowaved fruits.

Quality assurance tests (acid, peroxide and TBA values) elucidated that microwaves generally increased the olive oil stability of Picual and Shemlalli cultivars during storage. In addition, microwaves generated from oven ot moderate power setting for 12 min. exhibited an antioxidant power on olive oil equivalent to that possessed by $\mathrm{BHT}$ at $200 \mathrm{ppm}$.

KEY-WORDS: Antioxidant effect - Microwaves - Olive oil Stability.

\section{INTRODUCTION}

Olive tree has been cultivated for thousands of years around the Mediterranean sea. It is believed that olive trees originated from Africa (Egypt, Ethiopia) and spread to Mediterranean countries by the Phoenicians. Olive oil is one of the very few if not the only plant oil in the world which can be consumed in its natural state without being further treated or refined. Several studies indicated that olive oil may contribute to the prevention and control cardiovascular and other diseases (Viola and Audisio, 1987; Charbonnier, 1985; Laval-Jeantent et al., 1985; Rubba et al., 1985).

Deterioration of oil seeds during storage prior to crushing for oil production has a problem for oil seeds processing industry. If deterioration occurs, the free fatty acid level of the oil contained in the seed increases along with a concomitant decrease in its quality and economic value (Kiritsakis and Markakis, 1987; Kiritsakis, 1990). Like other vegetable oils, olive oil undergoes oxidative deterioration as a result of many factors (Papadopoulos and Boskou, 1991). The autoxidation of olive oil results in development of offflavour and odour and some of its physical properties may also be altered. The prevention of olive oil oxidation is of great importance from the stand point of palatability and economy. Various treatments including heating and soaking in a boiling water have been used to prevent the deterioration of oilseed qualities. However, these methods possess an adverse effects on seed components other than the oil such as phenolic acids and tocopherols (Yoshida et al., 1995; Nergiz and Unal, 1991). In addition, refrigeration of storage houses to keep seed temperature below $10^{\circ} \mathrm{C}$ could prevent deterioration. Draw air through the seed piles to reduce moisture content and temperature could also prevent free fatty acid formation but it may encourage oxidative rancidity process (Lusas, 1988).

As already mentioned hydrolytic and oxidative rancidity take place during olive fruits storage and processing and oil storage, Microwave energy has been used by food industry for warming, drying, thawing, sterilization and pasteurization (Yoshida et 
al., 1995). This energy is considered the most energyefficient type, most rapid method for heating of food items and commercially available (Tsuyuki, 1982). In the present investigation, the fruits of Shemlalli and Picual olive cultivars were exposed to microwaves generated from a microwave oven at moderate and low power settings for 3, 6, 9 and $12 \mathrm{~min}$. in an attempt to keep the quality of olive oil during storage. Consequently, the influence of microwave treatment on the physico-chemical properties, fatty acid pattern and quality assurance tests of the olive oil samples of both cultivars during storage was studied.

\section{MATERIALS AND METHODS}

\subsection{Source of olive fruits}

The ripe olive fruits of Shemlalli and Picual cultivars were obtained during the season 1994/1995 from Koum Osheim, El-Fayuom governorate.

\subsection{Treatment of olive fruits}

The fruits of Shemlalli and Picual cultivars were exposed to microwaves under the following conditions. Approximately $150 \mathrm{~g}$ of olive fruits were placed in Pyrex petri dishes (15 cm diameter by $2 \mathrm{~cm}$ high) and submitted to microwave heating at $2450 \mathrm{MHz}$ for 3, 6, 9 and $12 \mathrm{~min}$. in a domestic microwave oven (Model FM 13,935 Q, Moulinex, France) and when operated at full power it provides ca $1650 \mathrm{~W}$. The olive fruits in petri dishes were placed on a turn table which slowly rotated to ensure uniform heating. Two types of microwave oven settings were used, i.e., low and moderate power settings.

\subsection{Solvents}

All solvents used throughout the whole work were analytical grade and distilled before use.

\subsection{Standard compounds}

Pure standard fatty acids and butylated hydroxytoluene (BHT) were obtained from Sigma Chemical Company Ltd. (London, UK). Thiobarbituric acid (TBA) (98\%) was purchased from Aldrich Chemical Company Ltd. UK.

\subsection{Oil extraction}

The fruits of non-microwaved and microwaved olive fruits were ground, packed in a cheese cloth then pressed by using hydraulic laboratory (Craver) press. The extracted oil was dried over anhydrous sodium sulfate, filtered through a Whatman filter paper No. 1 and kept in brown bottles at $5^{\circ} \mathrm{C}$ till analysis.

\subsection{Physico-chemical properties}

Refractive index, acid value, peroxide value, iodine value, saponification number and unsaponifiable matter content were determined according to A.O.A.C. methods (1990). TBA test was carried out according to the method described by Ottolenghi (1959). Identification and qualitative determination of fatty acids were conducted according to Farag et al. (1992).

\subsection{Quality assurance tests}

Acid, peroxide and TBA tests were performed on olive oil samples of non-microwaved and microwaved Picual and Shemlalli fruits as parameters of olive oil quality. The olive oil samples were stored in brown bottles at room temperature $\left(30 \pm 2^{\circ} \mathrm{C}\right)$ and aliquots were periodically withdrawn for the determination of the above mentioned test. Each experiment for a particular test was conducted in triplicate and the mean values are presented in the tables.

\subsection{Statistical analysis}

The analysis of variance of the two factor factorial design was applied for all data under the present study according to the method outlined by Snedecor and Cochran (1973). The L.S.D. test was used to compare the significant differences between means of treatments (Waller and Duncan, 1969).

\section{RESULTS AND DISCUSSION}

\subsection{Physico-chemical properties of Picual and Shemlalli olive oils}

Table I shows the physical and chemical properties of the olive oil extracted from non-microwaved and microwaved Picual and Shemlalli fruits. The refractive index values at $25^{\circ} \mathrm{C}$ for the non-microwaved olive oil samples extracted from Picual and Shemlalli fruits were 1.4675 and 1.4684 , respectively. This means that the oils of both cultivars had nearly the same degree of unsaturation. The microwave treatment did not significantly change the refractive index of the oils of both cultivars. The acid values of olive oil samples of non-microwaved Picual and Shemlalli cultivars were 0.20 and 0.42 , respectively. Hence, the acid value of non-microwaved, Shemlalli oil was approximately 
decomposition some of the formed hydroperoxides and their degradation products are volatile in nature. Hence, microwaves decreased the hydroperoxide level in the olive oil samples. It is worth to mention that the peroxide values of the oils extracted from the fruits of both cultivars exposed to microwaves generated from oven at low and moderate power settings and for various periods were nearly the same. Hence, one would suggest to use the microwaves generated from an oven at low power settings for $3 \mathrm{~min}$. to maintain olive oil quality.

The iodine value, saponification value and unsaponifiable matter content of the oils extracted from the non-microwaved Picual and Shemlalli fruits were approximately the same. The data in Table I show that microwave treatment possessed no significant change in the values of the above mentioned parameters.

\subsection{Fatty acid composition of olive oils of Picual and Shemlalli cultivars}

The results of the physico-chemical constants of the olive oil samples under study demonstrated that microwave treatment generally did not alter the values of these constants compared with the non-microwaved oil. In order to emphasize the previous results, the fatty acids of the olive oil samples extracted from the nonmicrowaved and microwaved Picual and Shemlalli fruits were qualitatively and quantitatively determined by GLC. Table II shows the fatty acid patterns of the olive oil samples under investigation. Non-microwaved olive oil of Picual cultivars contained 8:0, 10:0, 12:0, $14: 0,18: 3$ and $20: 0$ acids as trace substances $(<1 \%)$. The fatty acids $16: 1,18: 0$ and $18: 2$ occurred as minor components $(<10 \%->1 \%)$. This fatty acid pattern was similar to that obtained with olive oil extracted from Shemlalli cultivar except for 18:3 where it present as a minor substance.

The fatty acid composition of olive oil samples obtained from both Picual and Shemlalli cultivars were in accordance with the fatty acid patterns reported by Fujii et al. (1986), Yassa et al. (1990) and Zeitoun et al. (1991). The data of these researchers demonstrated that oleic and palmitic acids were present as major unsaturated and saturated acids, respectively. The results in Table II show that microwave heating at low and moderate oven power settings for 9 and $12 \mathrm{~min}$. caused no significant differences in the fatty acid compositions of olive oil samples under study.

\subsection{Effect of microwave treatment on Picual and Shemlalli olive oil rancidity during storage}

Retardation of lipid rancidity is an important element of food preservation and can be a major factor in retention of palatability, nutritional quality and acceptability of a food (Fox, 1983). Synthetic
Table II

Fatty acid composition (\%) of olive oil extracted from fresh and microwaved Picual and Shemlalli fruits

\begin{tabular}{ccrrrr}
\hline & & \multicolumn{2}{c}{$\begin{array}{c}\text { Oow microwave } \\
\text { setting }\end{array}$} & $\begin{array}{c}\text { Moderate microwave } \\
\text { setting }\end{array}$ \\
\cline { 3 - 6 } & & (9 min.) & (12 min.) & (9 min.) & (12 min.) \\
\cline { 3 - 6 } Fatty acid & Control & \multicolumn{4}{c}{ Picual olive oil } \\
\hline $8: 0$ & 0.11 & 0.22 & 0.12 & 0.44 & 0.17 \\
$10: 0$ & 0.05 & 0.09 & 0.1 & 0.04 & 0.09 \\
$12: 0$ & 0.11 & 0.14 & 0.11 & 0.23 & 0.18 \\
$14: 0$ & 0.39 & 0.51 & 0.38 & 0.1 & 0.27 \\
$16: 0$ & 21.74 & 21.91 & 21.86 & 21.50 & 21.21 \\
$16: 1$ & 2.6 & 2.50 & 2.70 & 2.39 & 2.22 \\
$18: 0$ & 2.95 & 2.51 & 2.73 & 3.21 & 3.28 \\
$18: 1$ & 67.93 & 68.32 & 67.57 & 67.84 & 68.66 \\
18.2 & 2.88 & 2.73 & 2.90 & 3.11 & 2.73 \\
$18: 3$ & 0.66 & 0.54 & 0.93 & 0.63 & 0.61 \\
$20: 0$ & 0.58 & 0.53 & 0.60 & 0.51 & 0.58 \\
\hline
\end{tabular}

Shemlalii olive oil

\begin{tabular}{rrrrrr}
\hline $8: 0$ & 0.09 & 0.1 & 0.07 & 0.14 & 0.40 \\
$10: 0$ & 0.19 & 0.13 & 0.46 & 0.40 & 0.23 \\
$12: 0$ & 0.06 & 0.08 & 0.23 & 0.38 & 0.29 \\
$14: 0$ & 0.57 & 0.46 & 0.54 & 0.80 & 0.29 \\
$16: 0$ & 19.49 & 19.75 & 20.19 & 19.50 & 19.75 \\
$16: 1$ & 1.80 & 1.90 & 2.70 & 2.30 & 1.89 \\
$18: 0$ & 2.75 & 2.13 & 2.67 & 2.35 & 2.91 \\
$18: 1$ & 70.56 & 70.09 & 70.05 & 69.97 & 69.87 \\
18.2 & 2.31 & 3.50 & 2.10 & 2.10 & 2.50 \\
$18: 3$ & 1.32 & 1.15 & 1.59 & 1.14 & 1.14 \\
$20: 0$ & 0.86 & 0.71 & 0.40 & 0.92 & 0.73 \\
\hline
\end{tabular}

L.S.D. value at $P=0.05$ was 0.94

antioxidants used in food industry are phenolic compounds such as butylated hydroxy anisole (BHA), butylated hydroxy toluene (BHT), butylated hydroquinone (BHQ) and dodecyl gallate (DDG). Recently, there has been some discussion on the safety of the use of these synthetic antioxidants, since BHT causes changes in rat thyroid, stimulation of DNA synthesis, and induction of enzymes (Wurtzen et al., 1986, Namiki, 1990). Also, BHT and DDG exhibited remarkable increase in the amount of aflatoxins (carcinogenic agents) produced by Aspergillus parasiticus (Farag et al., 1989b).

Today much attention has been focused on using natural antioxidants. In this respect, the essential oils of thyme, cumin, and clove were individually added to butter and cotton seed oil and possessed remarkable antihydrolytic and antioxidant effects (Farag et al., 1989a, 1990). Spices, whole as well as ground, are known to be contaminated by heat resistant bacterial 
spores and molds (Farkas, 1988). The contaminated spice microflora can shorten market life of the products through spoilage and or conceivably contribute to consumer illness. In addition, the amount of the volatile oil obtained from plants by steam distillation is very low $(1-3 \%)$ and cannot cope with their needs. Hence, Picual and Shemlalli fruits were exposed to microwaves generated at low and moderate oven power settings for various periods in an attempt to suppress the deterioration of the extracted olive oil during storage. In addition, an experiment was conducted where Picual and Shemlalli olive oils were individually catalyzed by BHT (200 ppm) in order to compare its effectiveness with the microwave heating at moderate oven power setting as a method for retarding oil rancidity. The extracted olive oil samples obtained from non-microwaved and microwaved fruits were stored at room temperature and tested periodically until high oil rancidity values were obtained.

Figures 1, 2, 3 and 4 show the influence of microwave heating at low and moderate oven power settings for various periods on the acid values of olive oil samples obtained from Picual and Shemlalli cultivars during storage. The results demonstrated that microwave treatment significantly decreased the oil acid value (L.S.D. $=0.1$ at $P<0.05$ ). Low and moderate power microwave treatments induced a linear increase with time in the hydrolysis of Picual and Shemlalli oils as measured by acid value. The extent of Picual and Shemlalli oils hydrolysis was not dependent upon the microwave oven settings and heating periods. This is because the acid values of the oils extracted from microwaved fruits at moderate oven power setting were not significantly different than that found at low oven power setting during storage. In general, the acid values of olive oil samples of both cultivars at low and moderate microwave oven power levels were much lower than that of non-microwaved oils.

Figures 1 and 2 illustrate the effect of microwave heating at low oven power settings on the stability of Picual and Shemlalli olive oils. The results of peroxide values for non-microwaved and microwaved Picual olive oil showed a linear increase during storage. In general, microwaves at low oven power setting caused significant decrease in the peroxide value of Picual oil (L.S.D. $=0.35$ at $P<0.05)$. The regression coefficient values for peroxide values during storage of nonmicrowaved and that extracted from microwaved fruits for $3,6,9$ and $12 \mathrm{~min}$. were 0.46 and $0.35,0.34,0.32$, 0.3 , respectively. These values demonstrated that there were no significant differences between the peroxide values of the microwaved Picual oil exposed for different periods. The profiles of the oil peroxide values for the microwaved Shemlalli fruits were similar to that obtained from Picual oil.

Figures 3 and 4 demonstrate the changes of the peroxide values of olive oil samples extracted from non-microwaved and microwaved Picual and Shemlalli
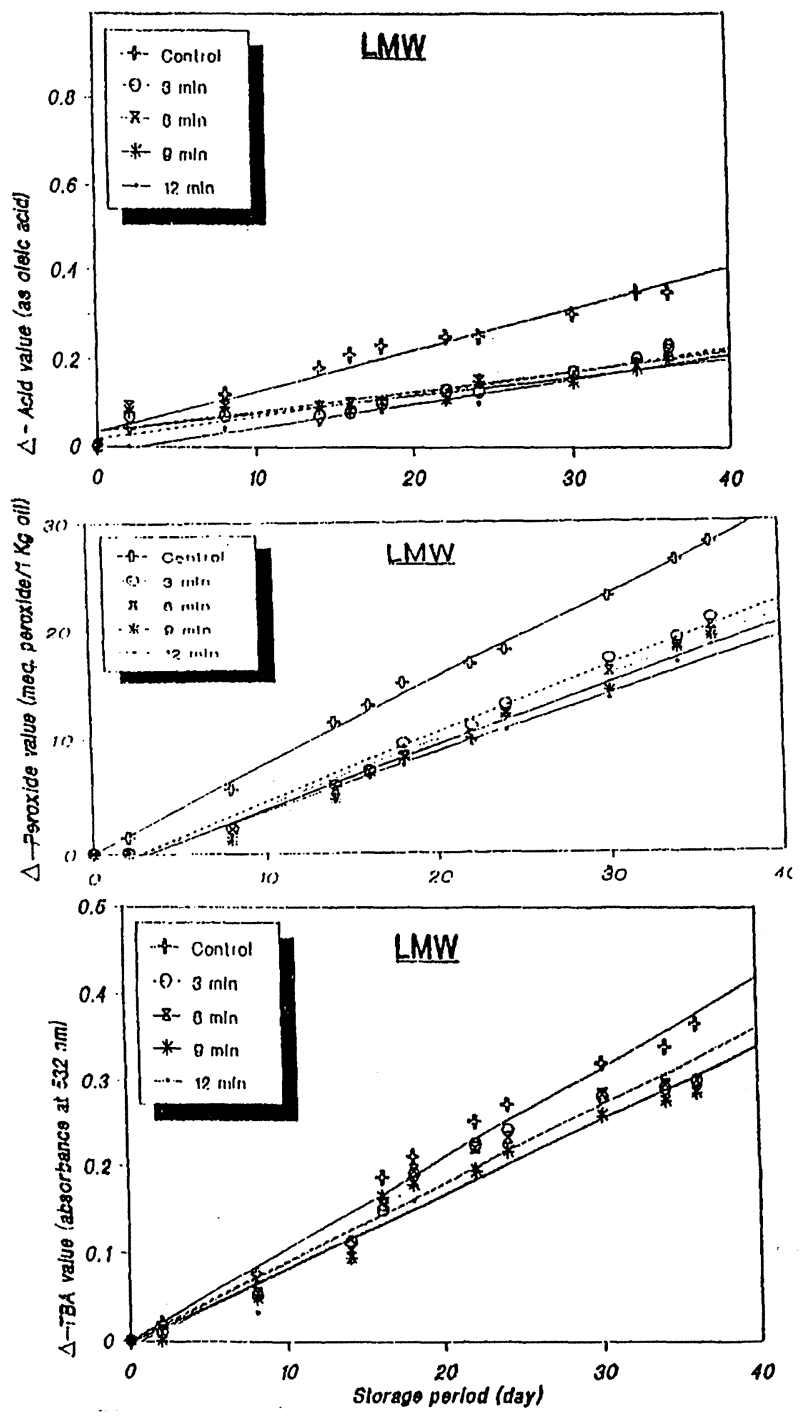

Figure 1

Influence of microwave heating at low power oven setting on the stability of Picual olive oil

fruits at moderate oven power setting for different periods during storage. Here again the peroxide values for non-microwaved Picual oil were linearly increased wih time. The slope values of peroxides of the oils extracted from non-microwaved and microwaved Picual fruits using moderate oven power setting for 3, 6, 9 and $12 \mathrm{~min}$. were 0.46 and 0.36 , $0.33,0.31,0.29$, respectively. These values demonstrate that microwaves at moderate oven power setting caused a significant depression of peroxide values (L.S.D. $=0.35$ at $P<0.05$ ) of Picual oil during storage compared with the non-microwaved fruits. However, no significant differences were found between the peroxide values of the microwaved oil samples exposed for different periods. The results of peroxide value of Shemlalli oil during storage were similar to that obtained from Picual oil. 

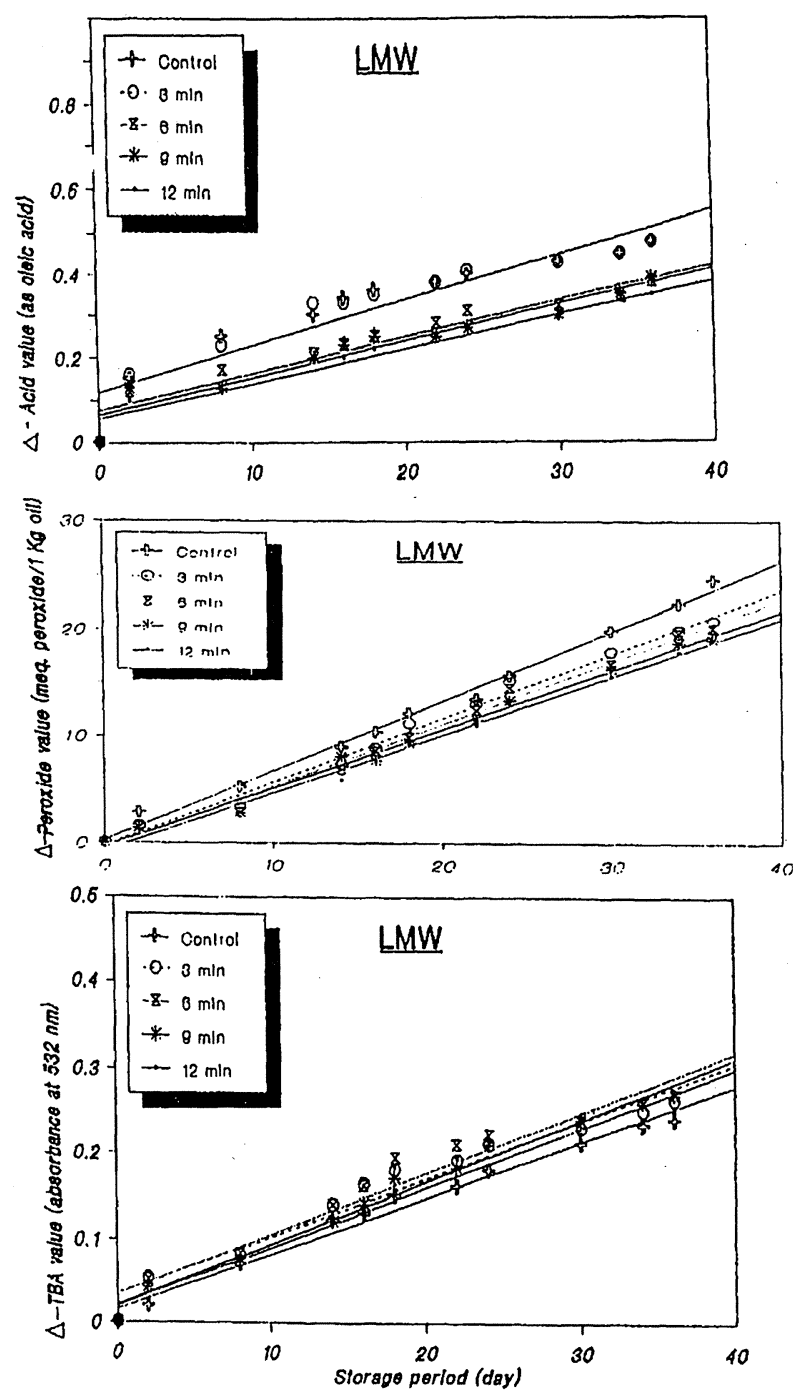

Figure 2

Influence of microwave heating at low power oven setting on the stability of Shemlalli olive oil

One has to point out that the maximum acid value for olive oil stored for 7 weeks was about 2 while the maximum peroxide value was approximately 40 for the same storage period. These values clearly indicate that olive oil rancidity was performed via an oxidative mechanism rather than the hydrolytic mechanism.

Figures 1, 2, 3 and 4 elucidate the changes in the TBA values of the extracted oils from Picual and Shemlalli fruits during storage. The microwave heating at low and moderate power settings for different periods caused a linear increase in the TBA value of picual oil during storage. The TBA values for the microwaved oil were always lower than that of the nonmicrowaved oil. However, no significant differences were recorded in TBA values of picual oil due to microwave heating for various periods. Concerning
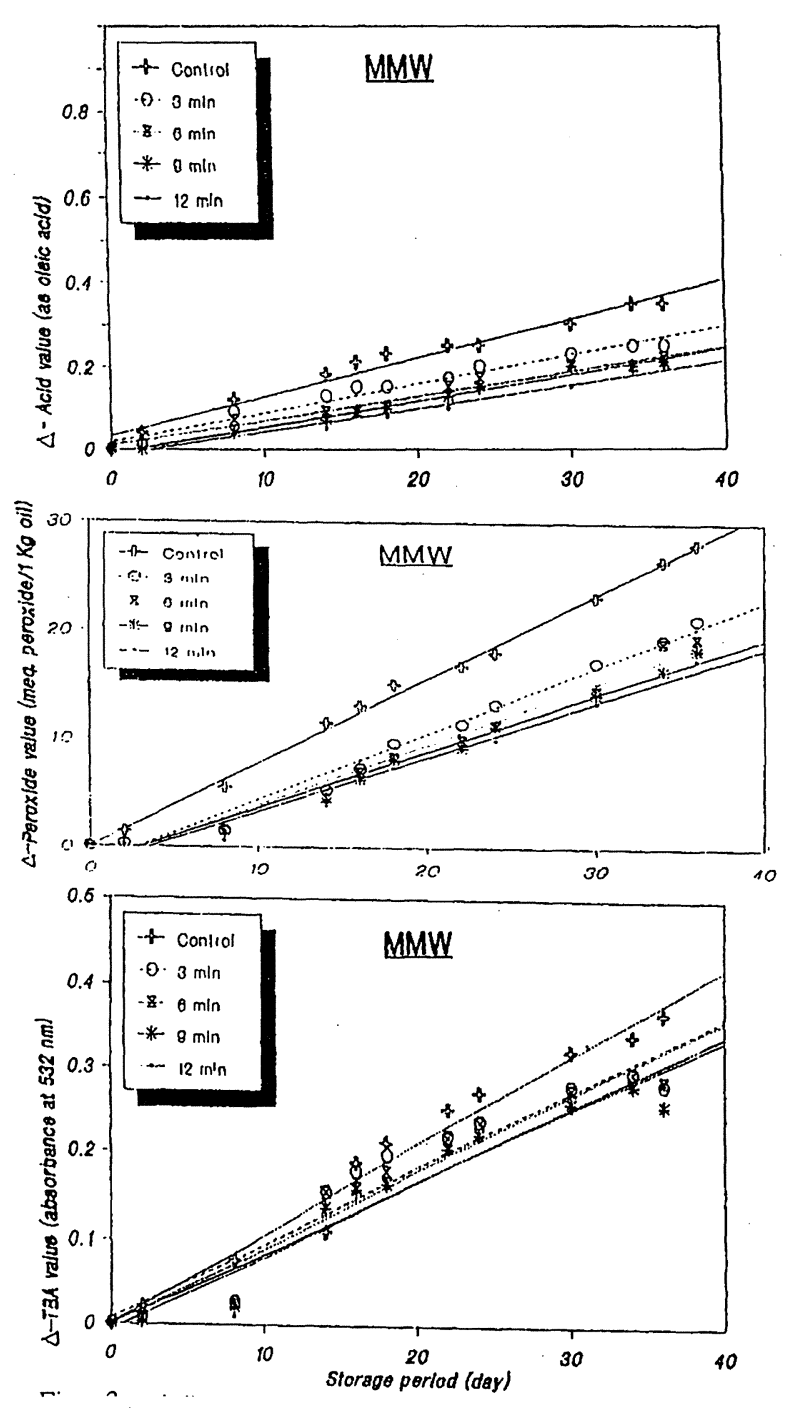

Figure 3

Influence of microwave heating at moderate power oven setting on the stability of Picual olive oil

Shemlalli oil, exposure to microwaves at low oven power setting possessed an increase in the TBA value over control. However, microwave heating for different periods caused no significant difference in TBA value during storage. Looking at microwaves generated from oven at moderate power setting caused a decrease in the TBA values compared with the control oil. However, the exposure for various periods to microwaves at moderate oven power setting showed no significant differences in TBA values.

All the mentioned data relevant to olive oil stability elucidated that exposure of Picual and Shemlalli fruits to microwaves at moderate oven power for 9 and 12 min. was the most effective method towards increasing the shelf-life of the extracted olive oil. It is well known that BHT is one powerful synthetic antioxidants. Hence, the antioxidant power between BHT and 

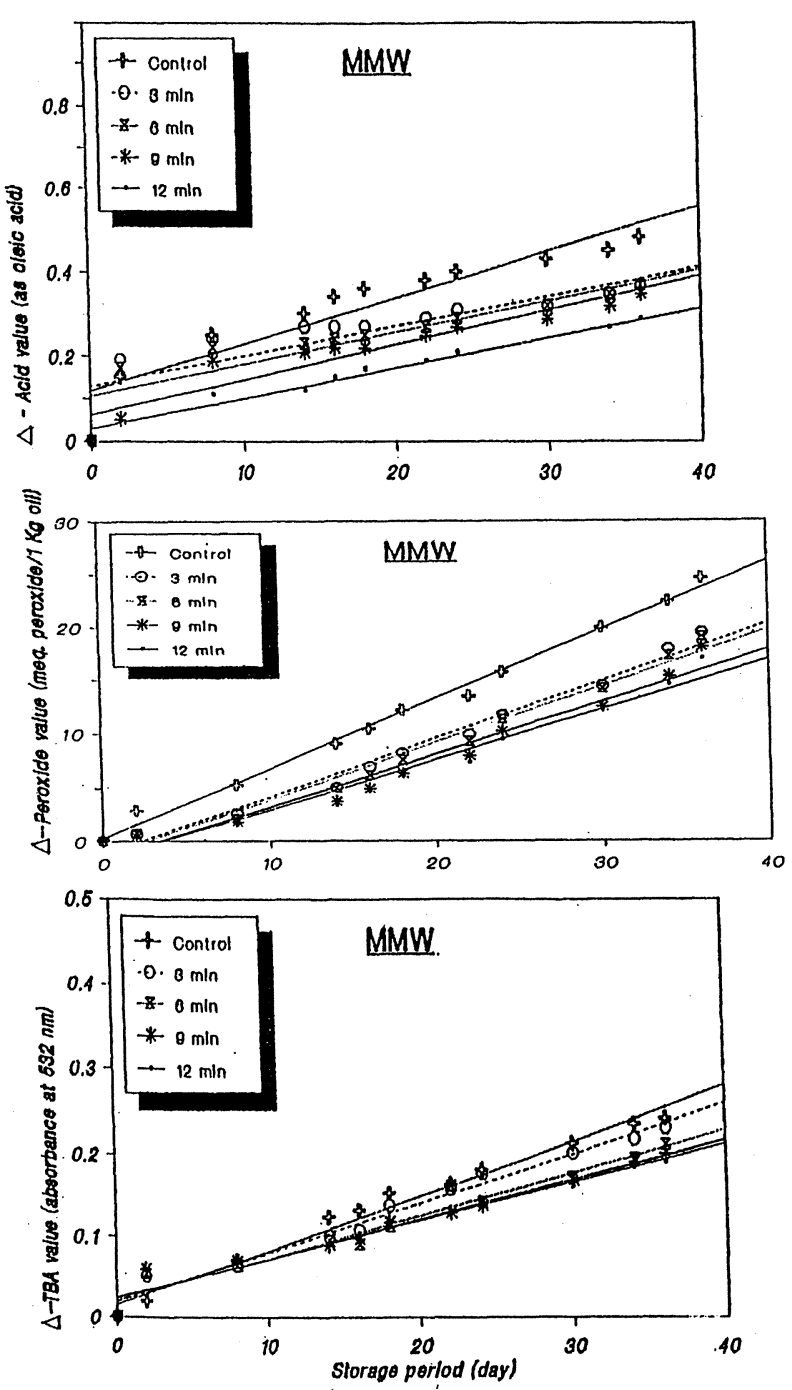

Figure 4

Influence of microwave heating at moderate power oven setting on the stability of Shemlalli olive oil

exposure to microwaves generated at moderate oven power setting was compared. Consequently, a set of experiments was conducted where BHT at $200 \mathrm{ppm}$ level was added to olive oil and an aliquots were taken periodically during storage for the determination of acid, peroxide and TBA values. These quality assurance tests were compared with the values obtained from the olive oil samples extracted from microwaved Picual and Shemlalli fruits.

Figure 5 shows the acid, peroxide and TBA values of Picual olive oil obtained from microwaved fruits as well as Picual olive oil mixed with BHT. The data demonstrated that the effectiveness of BHT as an antioxidant was similar to influence of exposing olive fruits to microwaves generated from oven at moderate power setting for $12 \mathrm{~min}$. Similar findings were obtained with Shemlalli oil (figure 6).

In conclusion, one would recommend to use the microwaves generated from oven at moderate power setting for $12 \mathrm{~min}$. for the following reasons. Microwave heating exhibited an antioxidant effect on olive oil equivalent to that possessed by BHT. In addition, BHT causes several harmfull effects for human health as previously mentioned whilst, microwaves as a natural phenomenon under the present conditions did not cause changes in the physico-chemical properties as well as the fatty acid composition of olive oil.

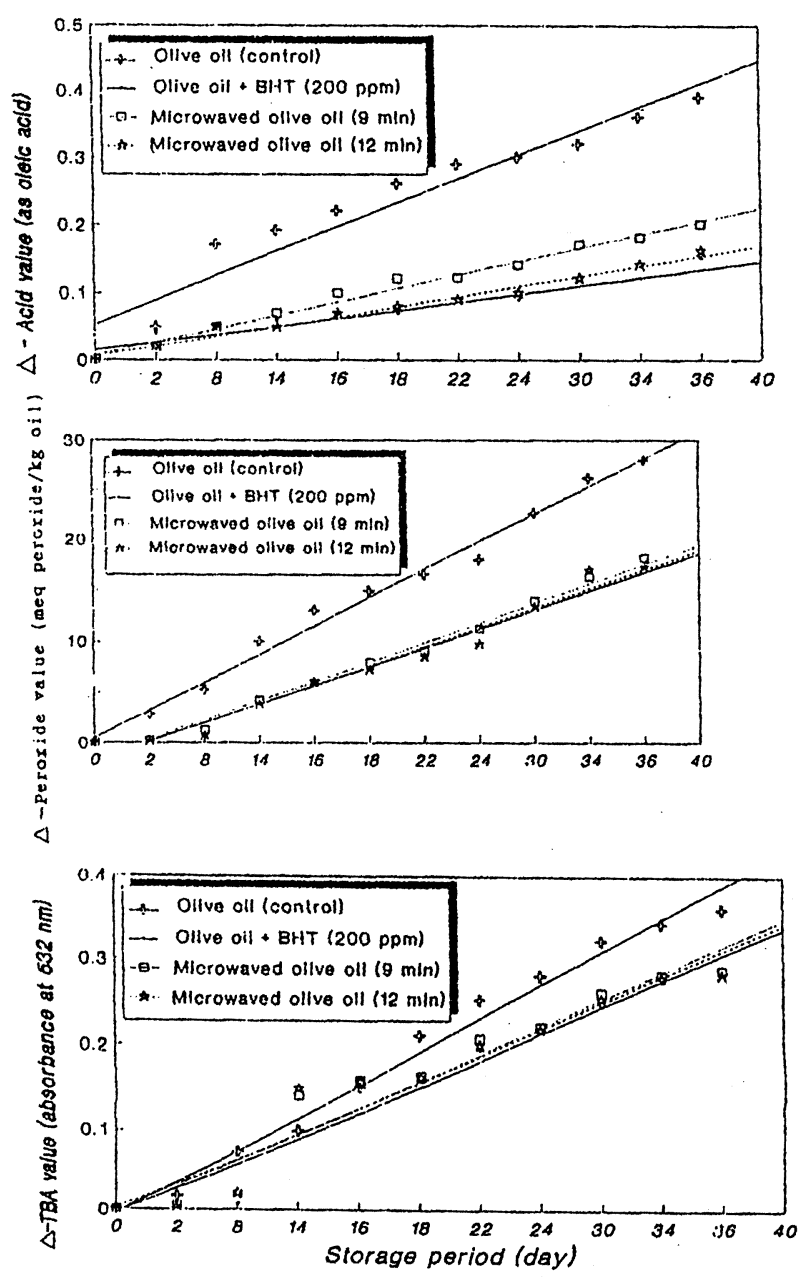

Figure 5

Changes in the stability of olive oil extracted from Picual olive fruits exposed to microwaves at moderate oven power setting 

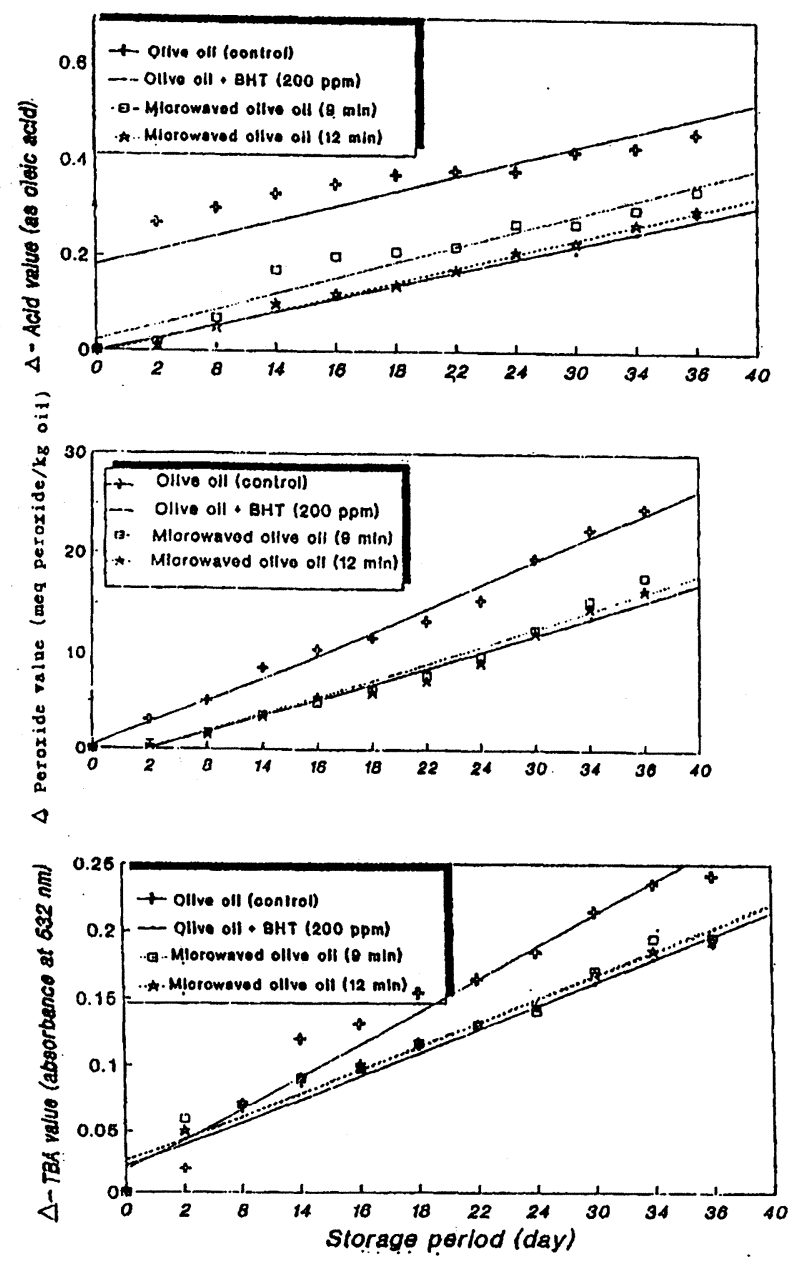

Figure 6

Changes in the stability of olive oil extracted from Shemlalli olive fruits exposed to microwaves at moderate oven power setting

\section{REFERENCES}

A.O.A.C. - "Official Methods of Analysis of the Association Official Analytical Chemists". (1990).- 15th. ed., Edited by W. Horwitz, AOAC, Washington, DC.

Charbonnier, A. (1985). - «Recenti acquisizioni sulvalore biologico dell'olio di olivae in Francia".- In 1st Congr. Nazionale di Terapia, Roma, Italia.

Farag, R. S., Ali, M. N. and El-Baroty, G. S. (1989a). - «Inhibitory effects of individual and mixed pairs of cottonseed oil and butter".- Grasas y Aceites 41, 248255.

Farag, R. S., Daw, Z. Y., Higazy, A. and Rashad, F. M. (1989b). - «Effects of some antioxidants on the growth of different fungi in a synthetic medium».- Chem. Mikrobiol. Technol. Lebensm. 12, 81-85.

Farag, R. S., Ali, M. N. and Taha, S. H. (1990). - Use of some essential oils as natural preservatives for butter".J. Am. Oil Chem. Soc. 68, 188-191.

Farag, R. S., Hewedi, F. M., Abu-Raiia, S. H. and El-Baroty, G. S. (1992). - "Comparative study on the deterioration of oils by microwave and conventional heating".- J. Food Protection 55, 722-727.
Farag, R. S., El-Baroty, G., Abd El-Aziz, N. and Basany, A. M. (1997). - «Stabilization of olive oil by microwave heating".- IJFSN (in press).

Farkas, J. A. (1988). - "Comparative analysis of spices decontaminated by ethylene oxide or gamma radiation".- Acta Alimentaria 17, 77-94.

Fox, P. E. (1983). - «Development in dairy chemistry of lipids".- Applied Sci. Publishers, London and New York, p. 241.

Fujii, T., Tatara, T. and Minagawa (1986). - «Studies on applications of lipolytic enzyme in detergency. I. Effect of lipase from Candida cylindracea on removal of olive oil from cotton fabric".- J. Am. Oil Chem. Soc 63, 796-799.

Kiriksakis, A. K. (1990). - "Olive oil».- Published by Am. Oil Chem. Soc., Champaign, Illinois.

Kiritsakis, A. K. and Markakis, P. (1987). - "Olive oil. A review's. - Advances in Food Research 31, 453.

Laval-Jeantent, A. M., Laval-Jeantent, M., Bergot, C. and Gousoud, J. (1985). - «Effects des lipides aleiques sur la croissance et la composition de l'os en nutrition experimentale».- In 3rd International Congress of Chanea, Crete, Greese.

Lusas, E. M. (1988). - "Preservation of high moisture cottonseed with propionic acid, presented at oil seed processing».- Clinic, New Orleans, LA., March, 14.

Namiki, M. (1990). -«Antioxidants/antimutagens in Foods».Crit. Rev. Food Sci. Nutr. 29, 273.

Nergiz, C. and Unal, K. (1991). - «Effect of method extraction on the total polyphenol, 1,2-diphenol content and stability of virgin olive oil»,- J. Sci. Food Agric. 56, 79-84.

Ottolenghi, A. (1959). - «Interaction of ascorbic acid and mitochondrial lipids".- Arch. Biochem. Biophys. 79, 355365.

Papadopoulos, G. and Boskou, D. (1991). -«Antioxidant effect of natural phenols on olive oil». $-J$. Am. Oil Chem. Soc. 68, 669-671.

Rubba, P., Mancini, M., Fidanza, F., Gautiero, G., Nikkari, T. and Oliver, M. F. (1985). - «Adipose tissue fatty acids and blood pressure in middle aged men from Southern Italy".- Proceeding 2nd. Int. Cong. on Essential Fatty acids, Prostaglandins and Leukotrienes, Ads., London.

Snedecor, C. W. and Cochran, W. C. (1973). - «Statistical Methods».- 6th edn. lowa State University Press, lowa, USA.

Tsuyuki, H. (1982). - «Utilization of high frequency and microwave heating in food industry".- J. Jpn. Soc. Food Sci. Technol. 29, 123.

Viola, P. and Audiso, M. (1987). - -Olive oil and health».International olive oil council, Madrid, Spain.

Waller, R. A. and Duncan, D. B. (1969). - A boys rule for symmetric multiple comparison problem».- Am. Stat. Assoc. J., pp. 1485-1503.

Wurtzen, G., Olsen, P. and Poulsen, E. (1986). - «The antioxidant butylated hydroxy toluene (BHT). A review of its toxicology and assessment of its safety in use".Food. Sci. Tech. Abs. 18 2T 18.

Yassa, A. I. Abdel-Basir, S. S. and Ahmed, R. T. (1990). - "Effect of different methods of processing on the nutritional value of Azizi and Picual table olives".- Annals Agric. Sci. 35, 775-786.

Yoshida, H., Mileno, A., Takagi, S., Yamaguchi, M. and Kajimoto, G. (1995). - «Microwave roasting effects on lipids in soybeans (Glycine $\max \mathrm{L}$.) at different moisture content».- J. Food Sci. 60, 801.

Zeitoun, M. A., Neff, M., Selke, W. E. and Mounts, T. L. (1991). - «Analyses of vegetable oil triglyceride molecular species by reversed phase high performance liquid chromatography».- J. Liquid Chromatography 14, 26852698.

Recibido: Mayo 1997 Aceptado: Octubre 1997 